\title{
EXERCISE AND MOTIVATION
}

\author{
W. H. WESSELS, D.M., D.P.M.*
}

\section{Summary}

A short history of the use of exercise in Medicine is given. This is followed by the neurophysiological basis of exercise and its physical and psychological effects on motivation in man.

Modern technological society, geared towards saving time, has succeeded admirably in reducing physical activity. Transport has virtually removed the need to walk or run, but fortunately from a health point of view, we are developing traffic congestion necessitating increased walking. In the everyday hustle and bustle of life, however, ambulation is considered a waste of time. Today we have reached the stage where the media urge us to 'let our fingers do the walking'.

: Professor and Head of Psychiatry, University of Natal, Durban

\section{Opsomming}

'n Kort geskiedenis van die gebruik van oefening in Geneeskunde word gegee. Dit word gevolg deur die neurofisiologiese basis van oefening en die fisiese en sielkundige uitwerkings op motiveering in die mens.

Early man was fortunate in that physical activity was a way of life - he had to remain physically in a peak condition simply to survive.

Confucius, about 2500 years ago said "Study the past if you would divine the future". Let us therefore, briefly retrace our footsteps through the passage of time.

Medicine and the allied professions developed from the pre-historic medicine-man who at that time represented all healing professions. He led us in the struggle against disease. The earliest painting of a medicine-man, clad in animal skins, with antlers attached to his head and a monkey mask on his face, was discovered in a cave in France. This painting 
was done some 20000 years ago. The medicine-man initially had been the magician, the physician and the priest.

Among the Egyptians, about 5000 years ago, healing was done by priest-physicians. Imhotep, the best known priestphysician, became the Egyptian God of Medicine. He designed the first pyramid, the great step pyramid at Memphis and recorded the first illness of the imagination and treated it successfully with incantations and magic rites.

From the sixth Century B.C. a dramatic change occurred under the influence of the Ionian philosophers because they nostulated natural causes of illness. Democritius believed that the world was composed of atoms and in order to remain healthy one had to keep the pores clean and the atoms moving. This could be accomplished by regular exercise. Aristotle extolled the virtues of the Corybanthic dances in the treatment of illness. Even at that time exercise was employed therapeutically.

Constantinus Africanus, in the 11 th Century, founded the Medical School of Salerno near Naples. He propagated the following treatment: Proper diet, kind and sensible words, music. baths, cathartics, rest, physical exercise and sexual gratification.

The dualistic philosophical postulate by René Descartes. laid the foundation for a philosophical system based on mathematical principles devoid of feelings. This dichotomy between body and mind continued to adversely influence medicine until the beginning of the 20th Century because it prevented holistic treatment of the sick.

During the 20th Century, due to technological advances, man exercised less and less. It was only during the second half of this century that regular exercise took its rightful place in the total treatment of illness. Regular, rhythmic, aerobic exercise today forms an integral part of preventative and curative measures advocated in most conditions.

We often fail, however, in establishing a regular pattern of exercise in those who need it most. Motivation to initiate new behaviour is dependent upon positive reinforcement or reward in order to establish new behaviour patterns. When a new behaviour pattern is followed this will not become fixed if accompanied by feelings of dislike.

Rewarding factors involved in learning more physically active behaviour probably have the following positive reinforcers:-

I. Stimulation of the vestibular apparatus has a strong rewarding effect in man because from a young age onwards it Iprovides a basic source of enjoyment in the human being. Babies for example, laugh if thrown into the air and small children spontaneously turn around and around or enjoy swinging.

2. One of the strongest positive reinforcers is the feeling of achievement and is very important in physical activity. The achievement of something previously impossible is especially gratifying. Such a person would then be competing with himself

3. The establishment and maintenance of new behaviour patterns are strengthened if the reward does not necessarily follow the new behaviour. To illustrate this one could compare a sweets dispenser to a one-armed bandit in a casino. The sweets dispenser gives virtually $100 \%$ reward when a coin is inserted. Should such a machine not produce the goods after insertion of a coin, very few people would insert a second coin. The same person, however, will insert coin after coin into a one-armed bandit which rewards only very infrequently.

4. Decrease in the feelings of tension and depression are by lar the strongest reinforcers. This relief is due to release of aggression in physical activity and to change in the neurotransmitter status following exercise.

The neurotransmitters are intimately involved on the biological level in the reward-aversion systems. The neurotransmitters involved are the biogenic amines noradrenaline and serotonin. Neurotransmitters connect one neuron via the synaptic cleft with the next neuron. Without the involvement of the biogenic amines, thought is not possible. There is a relative shortage of noradrenaline in depression and in anxiety there is a disturbance of the gamma-amino-butyricacid (GABA) systems. GABA, another neurotransmitter. mediates in the inhibitory system.

The reticular activating system (RAS) is intimately involved in arousal which is followed by feelings of tension. Histochemical studies have shown that the neurons in the reticular activating system contain noradrenaline and dopamine. There are, however, cells containing serotonin and it is postulated that the noradrenaline and serotonin neurons inhibit each other reciprocally. The noradrenergic system heightens the anxiety response and serotonin decreases it. During conditioning of laboratory animals it was discovered that noradrenaline was mainly responsible for the transmission of positive reinforcement and approach behaviour. It is theorised that when a neuron discharges, noradrenaline signals that the neuron should again discharge because the experience had been pleasurable (facilitation). Serotonin on the other hand signals aversion, is inhibitory and modulates aggressive and avoidance responses. This is important in learning new behaviour because a person tends to repeat pleasurable behaviour (facilitation) and avoids unpleasurable behaviour (inhibition).

Every neurotransmitter has a specific distribution in the brain. The neuronal network of serotonin originates in the raphe nuclei and spreads through the median fore-brain bundle to the cerebral cortex and spinal cord. Noradrenaline originates in the locus coeruleus and spreads through the whole cerebral cortex with multiple connections on the way.

Recent research has shown the presence of an endogenous morphine-like substance called endorphin. Its action being like morphine, disinhibits, relaxes and decreases pain.

Proper motivation in convincing the person of the necessity for increased physical activity is essential. This can be done by providing the necessary information concerning the advantages of exercise. The feeling of psychological and physical well-being should be emphasised and the advantages for the lungs, heart and circulatory system and the control of mass should be enumerated.

The necessary training and support should be available as soon as the person is ready to increase physical activity. They should know which exercises suit them best and how to execute them. Instruction on how to begin, the frequency of the exercise and exactly how to slowly increase and how far to increase exercise should be explained. The dangers of over-exercise or too rapid increase in exercise and what to do should they arise, must be gone into. It is absolutely essential that the patient should have all information at his finger tips. Attention should be given to the less important things like which clothes to wear, the correct shoes and where to acquire these and the where, when and how of exercising. As soon as the person starts exercising, the necessary positive reinforcement should be given by way of encouragement, approval and support. Reward through achievement will appear in time.

The physical condition should be monitored regularly especially in cases of pre-existing physical illness. In some cases where less strenuous exercise has been prescribed one should avoid boredom. It is often beneficial to prescribe 
exercise in these cases to be practised in groups or to couple it to a pleasant activity, for example excrcising on an ergocycle or rowing machine while watching a television programme

Positive rewards through exercise itself are the following:-

i. The movement during exercise stimulates the vestibular apparatus causing the pleasant feeling of happiness.

ii. The increase in the blood circulation will within limits, increase the cerebral circulation which in turn improves the feeling of mental exhaustion and depression.

iii. The increased cerebral circulation and the activation of the reward systems both cause a rise in noradrenergic activity with improvement in the mood. This result, however, is temporary only and it may be the reason why some people need the next exercise session in order to return the feeling of temporary euphoria. Such a person may become addicted to physical exercise.

Another reason for the so-called addiction to exercise is the production of endorphins during strenuous physical exercise. This substance is produced only during regular, prolonged, aerobic activity. Increase in endorphins causes the feeling of relaxation, euphoria and decrease in pain experienced by long distance runners.

Tension is also reduced through the normalization of the function of the reticular activating system. This is mediated through the increased physical sensations experienced during prolonged exercise.

The application of these principles would tend to establish regular exercise patterns once initiated.
These are some of the aspects of motivation, however, I do not profess to really know the answers, as in the words of Sir James Barrie "I am not young enough to know everything".

\section{Bibliography}

Goldstein, A. (1973): Behaviour therapy. In Current Psychotherapies, Ed. Corsini R. Itasca: F. E. Peacock Publ. Inc.

Green, A. R. and Costain D. W. (1981): Pharmacology and biochemistry of psychiatric disorders. Chichester: John Wiley and Sons.

King, L. J. (1974): A sensory integrative approach to schizophrenia. Amer. J. Occup. Ther., 28, 526-536.

Mathew, R. J., Meyer, J. S., Semchuk, K. M., Francis, D. J., Mortel, K. and Claghorn, J. L. (1980): Cerebral blood flow in depression. Lancet, $1,1308$.

Meyer, B. J. (1976): Die fisiologiese basis van geneeskunde. Pretoria: HAUM.

Meuer, V. and Chesser. E. S. (1970): Behaviour therapy in clinical psychiatry. Harmondsworth: Penguin Books.

Mora, G. (1967): History of Psychiatry. In Comprehensive Texibook of Psychialry, Eds. Freedman. A. M. and Kaplan, H. I. Baltimore: The Williams and Wilkins Co.

Rees, W. H., Smythies J. R. and Stein, L. (1976): Biochemical aspects of anxiety and depression. Leiden: Leiden Univ. Press.

Silverstone, T. and Turner, P. (1978): Drug treatment in psychialry, 2nd Ed. London: Routledge and Kegan Paul.

Solomon P. and Patch, V. D. (1974): History of Psychiatry, In Handbook of Psychiatry. 3rd Ed. Los Altos: Lange Med. Publ. 